\title{
PREPUTIAL GLAND OF THE MALE MOUSE: ATTRACTANT FUNCTION*
}

\author{
F. H. BRONSON AND D. CAROOM \\ Department of Zoology, University of Texas, \\ Austin, Texas 78712, U.S.A.
}

(Received 6th October 1970)

Preputial glands of male rodents have long been suspected as sites of pheromone secretion on the basis of little or no experimental evidence (e.g. Noble \& Collip, 1941; Spener, Mangold, Sansone \& Hamilton, 1969). The present report documents a signalling function for the preputial gland of the male house mouse, i.e. the male's gland apparently secretes a substance which acts as an attractant for females.

Two sets of experiments were conducted, both using sexually experienced C57BL/6 $\mathrm{J}$ females in random stages of their oestrous cycles. In the first set, a group of thirty-two females (6 to 8 months old) were tested for various odour preferences seven times in 5-min trials over an 8-week period. All females were individually housed and maintained between and during testing in the same room which contained no male mice. Test chambers utilized in Trials 1 to 3 were open-topped $23 \times 11 \times 6$-in. stainless steel boxes. Odour sources consisted of $1 \mathrm{ml}$ of various urines or saline homogenates absorbed on cotton sponges and contained within $1 \times 6 \times 2$-in. ventilated plastic boxes in the four corners of the test chamber. Urine or homogenates were pooled from adult C57BL/6J mice. More than one test chamber were used in order to randomize location without contamination from previous odour sources. All females were preconditioned to the test apparatus before Trial 1 by single 5-min exposures on each of 3 days with no odours present. Cumulative association times were recorded for each odour source during actual testing (association defined as at least the two front feet inside a line drawn 2 in. from each odour source). The data for each trial were then used to rank each female's preference for each odour and analysed by Friedman's two-way analysis of variance.

Significant preference was found in the first two trials for urine obtained from intact males when compared to urine from females, urine from males from which the preputial gland had been removed, or to an empty plastic container (Table 1). The third trial tested preference for homogenates of the preputial glands of a single male in $1 \mathrm{ml}$ of saline against pooled urine collected externally or from the bladder of intact males or against an empty container. Preputial homogenates were most often preferred.

Trials 4 to 7 were run on consecutive days and had two objectives: evaluation

* This investigation was supported by Public Health Grant HD-04149 from the National Institute of Child Health and Human Development. 
of the effectiveness of the preputial attractant in a larger test chamber and examination of the stability of the phenomenon during successive daily exposures. The test chamber was again open-topped but measured $4 \mathrm{ft}$ on each side. Odour sources consisted of $2 \mathrm{ml}$ urine from females or from males from which the preputial gland had been removed, and homogenized glands from two adult males in $2 \mathrm{ml}$ saline which were absorbed on cotton sponges and buried in wood shavings in the fenced-in corners. Three pre-conditioning exposures to the odour-free test chamber were given on consecutive days, after which testing began. Preputial homogenate was preferred over all other odour sources in all four trials. Table 1 presents the results of Trials 4 and 7 and indicates no damping out of the phenomenon.

TABLE 1

NUMBERS OF FEMALE MICE PREFERRING VARIOUS ODOUR SOURGES OVER ALL OTHER SOURGES AVAILABLE

\begin{tabular}{|c|c|c|c|c|c|c|}
\hline \multirow{3}{*}{$\begin{array}{l}\text { Trial } \\
1 \text { and } 2\end{array}$} & \multirow{3}{*}{$\begin{array}{c}\text { No. of } \\
\text { females }\end{array}$} & \multicolumn{4}{|c|}{ Odour sources } & \multirow{3}{*}{$\begin{array}{c}\mathrm{P}^{*} \\
<0.001\end{array}$} \\
\hline & & \multicolumn{3}{|c|}{ Comparisons and controls } & $\begin{array}{l}\text { Preputial } \\
\text { secretion }\end{array}$ & \\
\hline & & $\begin{array}{c}\text { Nothing } \\
\quad 8\end{array}$ & $\begin{array}{l}\text { Female } \\
\text { urine } \\
7\end{array}$ & $\begin{array}{l}\text { Urine of males } \\
\text { without } \\
\text { preputial glands } \\
15\end{array}$ & $\begin{array}{l}\text { Urine of } \\
\text { intact males } \\
34\end{array}$ & \\
\hline 3 & 29 & $\begin{array}{c}\text { Nothing } \\
5\end{array}$ & $\begin{array}{c}\text { Male urine } \\
\text { (bladder) } \\
5\end{array}$ & $\begin{array}{c}\text { Male urine } \\
\text { (external) } \\
\quad 2\end{array}$ & $\begin{array}{c}\text { Preputial } \\
\text { homogenate } \\
17\end{array}$ & $<0.001$ \\
\hline $\begin{array}{l}4 \\
7\end{array}$ & $\begin{array}{l}28 \\
28\end{array}$ & $\begin{array}{c}\text { Nothing } \\
2 \\
1\end{array}$ & $\begin{array}{c}\text { Female urine } \\
8 \\
4\end{array}$ & $\begin{array}{c}\text { Urine of males } \\
\text { without } \\
\text { preputial glands } \\
5 \\
7\end{array}$ & $\begin{array}{c}\text { Preputial } \\
\text { homogenate } \\
13 \\
16\end{array}$ & $\begin{array}{l}<0.01 \\
<0.001\end{array}$ \\
\hline
\end{tabular}

* Data presented are only in terms of 'most preferred odour source' while probabilities were calculated on the basis of all four rankings using Friedman's two-way analysis of variance.

$\dagger$ Thirty-two females in each trial.

A second set of experiments used a different group of thirty sexuallyexperienced females ( 8 to 12 months old) to determine (a) whether saline homogenates of some other male glands were similarly attractive and (b) whether or not the attraction factor in the male's preputial glands could be extracted as a lipid. Test females had been housed separately in $15 \times 12 \times 7$-in. polypropylene cages for 1 month. The testing procedure consisted of placing each home cage on a nearby table where it was left for $3 \mathrm{~min}$. Single drops of test and control substances were then simultaneously applied to the lips of the cages, one to each of the ends of the long axis of the cage. Observation periods ( $3 \mathrm{~min}$ ) followed immediately during which the cumulative time spent by the females within 3 in. of either end was recorded with stop watches. Animals showing less than $10 \mathrm{sec}$ difference in association at the two ends were noted as demonstrating no preference. Three consecutive tests were conducted to 
determine the attractiveness of saline homogenates of the submaxillary gland (Day 1), a combination of Harderian and lacrimal glands (Day 2), and the preputial gland (Day 3). Each type of tissue was homogenized in saline and tested against a control homogenate made from equal parts of muscle and abdominal fat that was equal in total wet weight to the test gland tissue sample. Tests against muscle-fat control (Table 2) showed no preference for either the submaxillary gland or the lacrimal-Harderian gland combination and reconfirmed the effect of the preputial gland.

Twenty-five females were tested again 2 weeks later to see if the preputial factor could be extracted with a lipid solvent. Preputial glands from a single C57BL/6J male were homogenized in saline and extracted with methylene chloride. The resulting oil was then emulsified in saline. A control mixture of muscle and abdominal fat equal in total weight to these preputial glands was similarly treated and the two mixtures tested in the manner described above.

\section{TABLE 2}

NUMBERS OF FEMALE MICE PREFERRING SALINE HOMOGENATES OF DIFFERENT GLANDS COMPARED TO A MUSCLE-FAT GONTROL HOMOGENATE, OR PREFERRING A METHYLENE GHLORIDE EXTRAGT OF THE PREPUTIAL GLAND VERSUS A SIMILAR EXTRAGT OF MUSGLE AND FAT

\begin{tabular}{l|c|c|c|c|c}
\hline & $\begin{array}{c}\text { No. of } \\
\text { females }\end{array}$ & $\begin{array}{c}\text { Test } \\
\text { gland }\end{array}$ & $\begin{array}{c}\text { Muscle- } \\
\text { fat control }\end{array}$ & $\begin{array}{c}\text { No } \\
\text { pref. }\end{array}$ & $\mathrm{P}$ \\
\hline $\begin{array}{c}\text { Submaxillary glands } \\
\text { (saline homogenate) }\end{array}$ & 30 & 16 & 12 & 2 & N.S. \\
$\begin{array}{c}\text { Lacrimal-Harderian glands } \\
\text { (saline homogenate) }\end{array}$ & 30 & 13 & 16 & 1 & N.S. \\
$\begin{array}{c}\text { Preputial glands } \\
\text { (saline homogenate) }\end{array}$ & 30 & 22 & 8 & 0 & $<0.01$ \\
$\begin{array}{c}\text { Preputial glands } \\
\text { (lipid extract) }\end{array}$ & 25 & 22 & 1 & 2 & $<0.001$ \\
\hline
\end{tabular}

The lipid extract of the preputial glands was greatly preferred (Table 2). The difference was particularly dramatic in terms of the total time spent in association with each substance for all twenty-five females; a total of $1938 \mathrm{sec}$ for the preputial gland extract versus $386 \mathrm{sec}$ for the control (an average per mouse of 77 versus $15 \mathrm{sec}$ ).

The male preputial gland apparently secretes a signalling pheromone which, acting olfactorily, attracts females, at least under the restricted conditions of laboratory testing. The two sets of experiments described here showed that the preputial gland factor was attractive to female mice whether it was contained in urine, in the form of a saline homogenate, or occurred as a lipid extract. This preference occurred in either a two- or four-choice situation, in both large and small test chambers and was stable for at least four consecutive tests. Incidental observations of mice meeting after periods of isolation had indicated considerable grooming and attention to the head area. Homogenates of the submaxillary gland or of a combination of Harderian and lacrimal glands were then also tested but were found to be no more attractive than a muscle-fat 
control mixture. It should be noted that recent work has implicated the preputial gland secretion in the elicitation of aggression among male mice (McKinney \& Christian, 1970; Mugford \& Nowell, 1970). The same pheromone might, therefore, be carrying information leading to aggression when perceived by males and to attraction on the part of females.

It should be emphasized that the females tested for responsiveness in the present experiments were in random stages of the oestrous cycle, but were all sexually-experienced. Such a procedure follows the conclusion of Carr, Loeb \& Dissinger (1965) that attraction of female rats to males is either dependent upon gonadal hormones or sexual experience, one factor being able to replace the other.

\section{REFERENCES}

Garr, W. J., Loeb, L. S. \& Dissinger, M. L. (1965) Responses of rats to sex odors. F. comp. physiol. Psychol. 59, 370.

McKinney, T. D. \& Christian, J. J. (1970) Effect of preputialectomy on fighting behavior in mice. Proc. Soc. exp. Biol. Med. 134, 291.

Mugrord, R. A. \& Nowell, N. W. (1970) The aggression of male mice against androgenized females. Psychonom. Sci. 20, 191.

Noble, R. L. \& ColdIP, J. B. (1941) A possible direct control of the preputial glands of the female rat by the pituitary gland and indirect effects produced through the adrenals and gonads by augmented pituitary extracts. Endocrinology, 29, 943.

Spener, F., Mangold, H. K., Sansone, G. \& Hamilton, J. G. (1969) Long-chain alkyl acetates in the preputial gland of the mouse. Biochim. biophys. Acta, 192, 516. 